\title{
Effect of Sulphur and Spacing on Yield and Economics of Safflower (Carthamus tinctorius L.)
}

\author{
Kethavath Narender*, Rajesh Singh and Ekta Singh
}

Department of Agronomy, Sam Higginbottom University of Agriculture, Technology and Sciences, Prayagraj, Uttar Pradesh, India

*Corresponding author

Keywords

Safflower, Spacing, Growth, Sulphur, Yield Attributes, and B: C Ratio

Article Info

Accepted:

18 January 2021

Available Online:

10 February 2021
A field experiment was conducted to determine the effect of sulphur and spacing on yield and economics of safflower. The experiment was laid out in randomized Block Design, with 8 treatments, each replicated trice, in the rabi 2019 with the different levels of Sulphur $(0,10,20,30 \mathrm{~kg} \mathrm{~S} / \mathrm{ha})$ and Spacing $(20 \mathrm{~cm} \times 10 \mathrm{~cm}, 30 \mathrm{~cm} \times 10 \mathrm{~cm})$ respectively at Crop Research Farm, Department of Agronomy, SHUATS, Prayagraj,(U.P). Application of Sulphur and Spacing significantly influenced the yield and economics. Addition of $30 \mathrm{~kg} \mathrm{~S} / \mathrm{ha}$ $+30 \mathrm{~cm} \times 10 \mathrm{~cm}$ recorded highest yield attributes and yield viz., Grain yield $(1604.44 \mathrm{~kg} / \mathrm{ha})$, Stover yield $(4515.21 \mathrm{~kg} / \mathrm{ha})$ and the Maximum gross return (100781.42 \%/ha), net return (73379.901 /ha) and B: C ratio (2.67).

\section{Introduction}

Oilseeds are of great value in nutritional demands of mankind, animal feeding, and medicine. Among them, safflower (Carthamus tinctorius L.) is an important annual industrial crop. Safflower is broadleaf oilseed crop of the family Asteraceae, predominantly adapted to dry land (Bahrami et al., 2014). It originated in southern Asia and is cultivated in China, India, Persia, Egypt, and Pakistan. In the world it was cultivated over an area 0.964 million hectare, and had a production of 0.651 million tones with average productivity of $827.9 \mathrm{~kg} / \mathrm{ha}$.
India is a major safflower growing country and contributes 60 per cent of the total world production. India ranks first in area and production of safflower grown across the world. In India, safflower is grown in an area of $1,78,400$ ha with a production of 1.453 lakh tons and productivity of $498 \mathrm{~kg} / \mathrm{ha}$ (Indiastat, 2012).

Safflower is an important oilseed crop of the world. In India, it is grown in winter season and accounts for about $8.0 \%$ of the value of total oilseeds produce. Safflower has a deep root system and thus, can capture leached nutrients below the rooting-zone of other 
crops. In northern India, sowing of safflower gets delayed due to late harvesting of longduration rice crop as well as in areas where moisture from rice fields cannot be receded out in time. Late sown safflower is exposed to high temperature during the reproductive phase, along with reduced growing season and consequently, results in reduced growth and productivity.

Sulphur application in suitable quantities through appropriate source may be the corrective measure to improve the safflower yield in such areas. Erdal et al.,(2006) reported that soil $\mathrm{pH}$ decreased with the application of $\mathrm{S}$, resulting in increases in nutrient concentration, plant nutrient uptake, chlorophyll concentration, root nodules and dry matter production Hence, an attempt was made to study the effect of Sulphur levels and sources on growth, yield and nutrient uptake parameters of safflower (Carthamus tinctorius L.) The deficiency of secondary and micronutrients is wide spread in many parts of the country due to cultivation of high-yielding varieties, intensive agriculture and increasing use of sulphur - free fertilizers in large quantities with concomitant decrease in use of organic manures. Oilseeds are energy- rich crops, so phosphorus and sulphur nutrition assumes greater importance in comparison to other nutrients. This application of these elements as they have becoming limiting factor for obtaining higher yields of several oilseed crops including safflower.

Propagation, Sowing and Spacing in Safflower Cultivation. Propagation is done by seeds. In India, usually this is sown as Rabi season crop from October to November. Avoid late sowing as this may result in low yield due to high temperatures before maturity of the crop. Actually, sowing time depends on the region/states. When it comes to spacing for pure or solo crop, row spacing of $45-50 \mathrm{~cm} \times 20-25 \mathrm{~cm}$ and for mixed crop or intercrop, row spacing of 20-25 cm x 20-25 $\mathrm{cm}$ and for rain-fed crop, a row spacing of 60 $\mathrm{cm}$ x 30-35 cm should be followed. Safflower is usually planted at a depth of 30 to $45 \mathrm{~mm}$. On an average, $10 \mathrm{~kg}$ of seeds are enough for covering 1 hectare land. Again seed rate depends on the area and variety. Healthy seeds of improved varieties should be selected for sowing. Find the high yielding cultivar for your region from agriculture department.

\section{Materials and Methods}

The experiment was carried out during Rabi season of 2019 at Crop Research Farm, Department of Agronomy, Naini Agricultural Institute, SHUATS, Prayagraj (U.P).The soil of the experimental plot was sandy loam in texture, nearly neutral in soil reaction $(\mathrm{pH}$ 7.2), low in organic carbon $(0.58 \%)$, medium in available $\mathrm{N}(238 \mathrm{Kg} / \mathrm{ha})$, high in available $\mathrm{P}(32.10 \mathrm{Kg} / \mathrm{ha})$ and low in available $\mathrm{K}(189$ $\mathrm{Kg} / \mathrm{ha}$ ). The treatment consisted of 4 levels of sulphur viz. S0 (0 Kg S/ha), S1 (10 Kg S/ha), S2 (20 Kg S/ha) S3 (30 Kg/ha) and 2 levels of spacing $(20 \mathrm{~cm} \times 10 \mathrm{~cm})$ and $(30 \mathrm{~cm} \times 10 \mathrm{~cm})$. There are 8 treatments each replicated thrice. The experiment was laid out in Randomized Block Design. It was sown on 7th December 2019 with recommended doses of nitrogen phosphorous and potassium were applied.

\section{Results and Discussion}

\section{Yield}

Application of $30 \mathrm{~kg} / \mathrm{ha}+30 \mathrm{~cm} \mathrm{x} 10 \mathrm{~cm}$ recorded the highest and significant grain yield (1604.44 /ha) and stover yield (4515.21 $\mathrm{kg} / \mathrm{ha}$ ). Seed yield significantly varied with row spacing and levels of sulphur. (Ali Zadeh et al., 2012), Sharif Maghaddasi and Omidi (2016) also reported that seed yield increase using $30 \mathrm{~cm}$ row spacing. Also plant spacing effect was significant on seed yield. Many researchers studied row spacing and plant 
distance effect in safflower crop and demonstrated that low to medium densities produced more seed yield but in too narrow plant spacing, yield reduced due to increasing competing to uptake water, nutrients and light (Emami et al., 2011; Zarei et al., 2011; Hamza,2015)With increasing supply of sulphur the process of tissue differentiation from somatic to reproductive, meristematic activity and development of floral primordial might have increased, resulting in more flowers and capsules and longer capsules as reported by Jat and Mehra (2007). Increase in stover yield can be ascribed to the overall improvement in plant organs associated with faster and uniform vegetative growth of the crop under the effect of sulphur application. Similar results were reported by Singh (2001).

Table.1 Effect of Sulphur and Spacing on yield and Economics of Safflower

\begin{tabular}{|c|c|c|c|c|c|c|}
\hline Treatment Combinations & $\begin{array}{c}\text { Grain } \\
\text { yield } \\
\text { (kg/ ha.) }\end{array}$ & $\begin{array}{c}\text { Stover } \\
\text { yield } \\
\text { (kg/ ha.) }\end{array}$ & $\begin{array}{c}\text { Cost of } \\
\text { production } \\
\text { (Rs./ha) }\end{array}$ & $\begin{array}{c}\text { Gross } \\
\text { return } \\
\text { (Rs./ha) }\end{array}$ & $\begin{array}{c}\text { Net } \\
\text { return } \\
\text { (Rs./ha) }\end{array}$ & $\begin{array}{c}\text { B:C } \\
\text { Ratio }\end{array}$ \\
\hline$T_{1} 0 \mathrm{~kg} / \mathrm{ha}+20 \mathrm{~cm} \times 10 \mathrm{~cm}$ & 1032.03 & 3029.30 & 22570.8 & 64951.09 & 42380.29 & 1.87 \\
\hline$T_{2} 0 \mathrm{~kg} / \mathrm{ha}+30 \mathrm{~cm} \times 10 \mathrm{~cm}$ & 1097.73 & 3235.68 & 22570.8 & 69099.47 & 46528.67 & 2.06 \\
\hline $10 \mathrm{~kg} / \mathrm{ha}+20 \mathrm{~cm} \times 10 \mathrm{~cm}$ & 1247.16 & 3184.27 & 24181.04 & 78013.87 & 53832.83 & 2.22 \\
\hline $10 \mathrm{~kg} / \mathrm{ha}+30 \mathrm{~cm} \times 10 \mathrm{~cm}$ & 1314.40 & 3490.30 & 24181.04 & 82354.29 & 58173.25 & 2.40 \\
\hline $20 \mathrm{~kg} / \mathrm{ha}+20 \mathrm{~cm} \times 10 \mathrm{~cm}$ & 1389.76 & 3715.44 & 25791.28 & 87101.04 & 61309.76 & 2.37 \\
\hline $20 \mathrm{~kg} / \mathrm{ha}+30 \mathrm{~cm} \times 10 \mathrm{~cm}$ & 1509.87 & 3742.02 & 25791.28 & 94334.22 & 68542.94 & 2.65 \\
\hline $30 \mathrm{~kg} / \mathrm{ha}+20 \mathrm{~cm} \times 10 \mathrm{~cm}$ & 1495.74 & 3891.68 & 27401.52 & 93636.07 & 66234.55 & 2.41 \\
\hline $30 \mathrm{~kg} / \mathrm{ha}+30 \mathrm{~cm} \times 10 \mathrm{~cm}$ & 1604.44 & 4515.21 & 27401.52 & 100781.42 & 73379.90 & 2.67 \\
\hline $\operatorname{SEm}( \pm)$ & 26.80 & 24.21 & - & - & - & - \\
\hline $\operatorname{CD}(p=0.05)$ & 79.65 & 74.91 & - & - & - & - \\
\hline
\end{tabular}

\section{Economics}

Cost of production (Rs./ha): The maximum cost of production was recorded under $\mathrm{T}_{8}(30$ $\mathrm{kg} / \mathrm{ha}+30 \mathrm{~cm} \times 10 \mathrm{~cm})(27401.52 \mathrm{Rs} . / \mathrm{ha})$.

Gross return (Rs./ha): Higher gross return was found in (100781.42 Rs./ha) $\mathrm{T}_{8}(30 \mathrm{~kg} / \mathrm{ha}$ $+30 \mathrm{~cm} \mathrm{x} 10 \mathrm{~cm})$.

Net return(Rs./ha): Higher Net return was found in (73379.90 Rs./ha) $\mathrm{T}_{8}(30 \mathrm{~kg} / \mathrm{ha}+30$ $\mathrm{cm} \times 10 \mathrm{~cm})$.

B: C ratio: Higher $B$ : $C$ Ratio was found in (2.67) $\mathrm{T}_{8}(30 \mathrm{~kg} / \mathrm{ha}+30 \mathrm{~cm} \mathrm{x} 10 \mathrm{~cm})$.

In conclusion, it is inferred from the present investigation that application of $30 \mathrm{~kg} / \mathrm{ha}+30$ $\mathrm{cm} \times 10 \mathrm{~cm}$ in addition to the full doses of nitrogen and potassium is recommended for farmers for receiving higher yield and economic benefits of Safflower.

\section{References}

Ali Zadeh, K.N., R. Naseri, A. Mirzaei and A. Soleymanifard.( 2012). Effects of planting pattern on yield, its components, oil contain and some important agronomic traits of Safflower (Carthamus tinctorius L.) in dry land conditions. International Journal of Agriculture and Crop Sciences4(2): 8691.

Bahramik.N,.(2014). Effects of planting pattern on yield, its components, oil contain and some important agronomic traits of Safflower (Carthamus tinctorius L.) in dry land conditions. 
International Journal of Agriculture and Crop Sciences 4(2): 86-91.

Emami, T., R. Naseri, H. Falahi and E. Kazemi.(2011). Response of Yield, Yield Component and Oil Content of safflower (cv. Sina) to Planting Date and Plant Spacing on Row in rainfed Conditions of Western Iran, AmericanEurasian Journal Agriculture and Environmental Science.10(6): 947-953.

Erdal E. (2006). Influence of sulphur fertilization on seed and oil yield, sulphur uptake in sesame. Advances in Plant Science, 19(1): 109- 112.

Hamza, M. (2015). Influence of different plant densities on crop yield of six safflower genotypes under Egyptian newly reclaimed soils conditions. International Journal of Agriculture and Crop Sciences. 8(2): 168-173.

Indiastat R.M,. (2012). Effects of plant population on growth, development and oil yield of safflower. Journal of Agricultural Science and Technology; 3:321-333.

Jat, J.R. and Mehra, R.K. (2007) Effect of sulphur and zinc on yield, macronutrient content in and uptake by mustard on haplustepts. Journal of the Indian Society of Soil Science, 55:190-95.

Omidi, A.H., H. Khazei. (2016). Effect Of Cultivar And Water Regime On Yield And Yield Components In Safflower (Carthamus tinctorius L.). Turkish Journal of Field Crops 17(1): 10-15.

Sharif Moghaddasi, M. and A.H. Omidi. (2016). Determination of optimum rowspacing and plant density in Goldasht safflower variety. Scientific Papers, Series A. Agronomy.8:301-306.

Singh, S.P. and Singh, V. (2001) Effect of nitrogen sulphur and zinc on Indian mustard (Brassica Juncea)Indian Journal of Agricultural Sciences. 75(12): 828-30.

Zarei, G., H. Shamsi and F. Fazeli.(2011). Effect of Plant Density on Yield and Yield Components of Safflower Cultivars in Spring Planting. World Academy of Science, Engineering and Technology. 5(12): 929-931.

\section{How to cite this article:}

Kethavath Narender, Rajesh Singh and Ekta Singh. 2021. Effect of Sulphur and Spacing on Yield and Economics of Safflower (Carthamus tinctorius L.). Int.J.Curr.Microbiol.App.Sci. 10(02): 424-427. doi: https://doi.org/10.20546/ijcmas.2021.1002.050 